\title{
ANALISIS PENGENDALIAN KUALITAS PRODUK GARMENT PADA PROJECT IN LINE INSPECTOR DENGAN METODE SIX SIGMA DI BAGIAN SEWING PRODUKSI PADA PT BINTAN BERSATU APPAREL BATAM
}

\author{
Monica Elisa Napitupulu ${ }^{1)}$, Shinta Wahyu Hati ${ }^{2)}$ \\ 1) Prodi Administrasi Bisnis Terapan Politeknik Negeri Batam, mail: monicaelisa6@gmail.com \\ 2) Prodi Administrasi Bisnis Terapan Politeknik Negeri Batam, mail: shinta@polibatam.ac.id
}

\begin{abstract}
Competition among competitors in the increasingly tight business world today encourages companies to develop more effective and efficient way in achieving the goals and objectives that have been set. With the current information and technology consumers become more sensitive about quality and price of a product. Therefore, companies are required to improve the quality of products produced and continuously improve and improve. PT Bintan Bersatu Apparel Batam is one of the manufacturing companies engaged in the production of sportswear. PT Bintan Bersatu Apparel also strives to continuously improve the quality by pressing the product number in the product process in this company. Six sigma as an alternative to the principles of quality control, enabling companies to improve with the actual breakthrough. Six sigma is an important tool for production management to maintain, maintain product quality and improve quality towards zero defect. So six sigma is a method or technique. Which is a new breakthrough in the field of quality management. By using six sigma method can be known quality sportswear produced PT Bintan Bersatu Apparel in 3.55 sigma with damage level of 20,290 for one million production (DPMO). Six sigma quality improvement in this research can be concluded there are three causes of the product: workmanship or constructionas much as $82.04 \%$, fabric as much as $13.82 \%$ and accessories as much as 4.14\%.In this research data analysis used Six Sigma (DMAIC) method which through five stages that is define, measure, analyze, improve and control.
\end{abstract}

Keywords : DMAIC ,DPMO, FMEA, Quality, Six Sigma

abstrak

Persaingan antar kompetitor di dunia usaha yang semakin ketat saat ini mendorong perusahaan untuk lebih mengembangkan cara yang efektif dan efisien dalam mencapai sasaran dan tujuan yang telah ditetapkan. Dengan adanya informasi dan teknologi saat ini konsumen menjadi lebih peka terhadap kualitas dan harga suatu produk. Oleh sebab itu, perusahaan dituntut untuk meningkatkan kualitas produk yang dihasilkan dan terus menerus memperbaiki dan memperbaharui strategi. PT Bintan Beratu Apparel Batam merupakan salah satu perusahaan manufaktur yang bergerak dalam bidang produksi pakaian olahraga. PT Bintan Bersatu Apparel juga berusaha untuk terus meningkatkan kualitas dengan menekan angka produk cacat dalam proses produks di perusahaan ini. Six sigma sebagai salah satu alternatif dalam prinsip-prinsip pengendalian kualitas, memungkinkan perusahaan melakukan peningkatan dengan terobosan yang actual. Six sigma merupakan alat penting bagi manajemen produksi untuk menjaga, mempertahankan kualitas produk dan terutama untuk mencapai peningkatan kualitas menuju zero defect. Jadi six sigma merupakan suatu metode atau teknik pengendalian dan peningkatan kualitas dramatik yang merupakan terobosan baru dalam bidang manajemen kualitas. Dengan menggunakan metode six sigma dapat diketahui bahwa kualitas pakaian olahraga yang dihasilkan PT Bintan Bersatu Apparel berada pada 3,55 sigma dengan tingkat kerusakan sebanyak 20.290 untuk sejuta produksi (DPMO). Implementasi peningkatan kualitassix sigma pada penelitian ini dapat disimpulkan bahwa ada tiga penyebab produk cacat tertinggi yaitu: workmanship atau construction sebanyak $82.04 \%$, fabric sebanyak $13,82 \%$ dan accessories sebanyak $4.14 \%$. Dalam penelitian ini analisis data yang digunakan adalah metode Six Sigma (DMAIC) yang melalui lima tahapan analisis yaitu define, measure, analyze, improve, dan control.

Kata Kunci : DMAIC, DPMO, FMEA, Kualitas, Six Sigma 


\section{PENDAHULUAN}

Di era globalisasi seperti saat ini,perkembangan perusahaan manufaktur didunia sangat cepat dan pesat. Mengingat hal itu maka setiap perusahaan yang ingin membangun perusahaannya menjadi perusahaan yang tetap hidup dan berkembang ditengah banyaknya persaingan harus memiliki persiapan dalam menghadapi kompetitorkompetitor dari negara lain. Batam merupakan salah satu kota industry yang berada di Indonesia, dilihat dari letak geografisnya yang berbatasan dengan Singapura dan Malaysia, Batam bisa dikatakan merupakan kota yang cukup strategis untuk pertumbuhan industri yang pesat. Menurut Kuncoro (2007) ada yang berusaha memacu pembangunan ekonomi dengan ekspansi perdagangan internasional dan sekaligus membuka pintu lebar-lebar terhadap investasi asing, bantuan luar negeri dan imigrasi,dari pernyataan tersebut maka kota Batam sudah cukup layak untuk menjadi salah satu kota industri yang banyak dikunjungi oleh para investor.

Menurut data yang didapat melalui situs SKPD Batam kota bidang industri, kawasan industri di Batam dapat dibagi menjadi dua golongan diantaranya: kawasan industri ringan dan kawasan industri berat. Kawasan industri ringan itu sendiri meliputi industri manufacturing, industri elektronika, industri garment, industri plastik dan lainnya,sedangkan kawasan industri berat di dominasi oleh industri galangan kapal, industri fabrikasi, industri baja, industri logam dan lainnya, membuat industri ini kini semakin berkembang pesat di Batam. Berdasarkan data yang telah didapatkan dari Disperindag ESDM kota Batam bidang industri jumlah industri yang berkembang di pulau batam dari tahun 2001-2012 mencapai 152 perusahaan yang dilihat dari jenis industi yang dijalankan. Dari data diatas juga dapat dilihat jenis industi yang sangat besar terdapat di kota Batam adalah industri pembuatan atau perbaikan kapal sebanyak 45 perusahaan, dan industri pakaian jadi dari tekstil dan perlengkapannya sebanyak 21 perusahaan.
Tabel 1 Jumlah Industri Berdasarkan Jenis Industrinya

\begin{tabular}{|c|c|c|c|}
\hline No & JENIS INDUSTRI & $\begin{array}{c}\text { JUMLAH } \\
\text { PERUSAH } \\
\text { AAN } \\
\end{array}$ & KLUI \\
\hline 1 & $\begin{array}{l}\text { Industri } \\
\text { Pembuatan/Perbaikan } \\
\text { Kapal }\end{array}$ & 45 & 35111 \\
\hline 2 & $\begin{array}{l}\text { Industri Kemasan dalam } \\
\text { Plastik }\end{array}$ & 14 & 25205 \\
\hline 3 & $\begin{array}{l}\text { Industri Barang dari } \\
\text { Kayu/Gabus yang Tidak } \\
\text { di Klasifikasikan } \\
\text { ditempat lain }\end{array}$ & 13 & 20299 \\
\hline 4 & Industri roti dan lainnya & 6 & 154110 \\
\hline 5 & $\begin{array}{l}\text { Industri Air Minum } \\
\text { dalam Kemasan }\end{array}$ & 6 & 15542 \\
\hline 6 & $\begin{array}{l}\text { Industri Pakaian Jadi } \\
\text { dari Tekstil \& } \\
\text { Perlengkapannya }\end{array}$ & 21 & 18101 \\
\hline 7 & $\begin{array}{l}\text { Industri Molding dan } \\
\text { Komponen Bahan } \\
\text { Bangunan }\end{array}$ & 6 & 20220 \\
\hline 8 & $\begin{array}{l}\text { Industri Kemasan dan } \\
\text { Kotak dari Kertas dan } \\
\text { Karton }\end{array}$ & 10 & 21020 \\
\hline 9 & Industri Percetakan & 18 & 22210 \\
\hline 10 & Industri Film dan Video & 1 & 22302 \\
\hline 11 & $\begin{array}{l}\text { Industri Barang-barang } \\
\text { Peralatan Teknik }\end{array}$ & 12 & 25906 \\
\hline
\end{tabular}

Sumber : Disperindag ESDM Kota Batam Bidang Industri (2001-2012)

Melihat dari beberapa data yang telah dipaparkan diatas industri-industri yang berkembang di kota Batam berasal dari industri galangan dan industri manufaktur pada bidang tekstil. Industri manufaktur sendiri memiliki pengertian yang sangat luas. Kata industri sering disebut sektor industry manufaktur/ pengolahan yaitu salah satu lapangan usaha dalam perhitungan pendapatan nasional menurut pendekatan produksi (Hastina, 2007). Berbicara mengenai industri manufaktur tidak akan pernah lepas hubungannya dengan masalah produk yang akan dihasilkan. Menurut Stanton yang dikutip oleh Buchari Alma dalam bukunya Manajemen Pemasaran Jasa (2007) mendefinisikan produk sebagai berikut: "Produk adalah seperangkat atribut baik berwujud maupun tidak berwujud, termasuk di dalamnya masalah warna, harga, nama baik pabrik, nama baik toko yang menjual (pengecer), dan pelayanan pabrik serta 
Monica \& Shinta, analisis pengendalian kualitas produk garment pada project in line inspector ....

pelayanan pengecer, yang diterima oleh pembeli guna memuaskan keinginannya."

Dari pengertian produk diatas dapat diambil kesimpulan bahwa suatu produk memiliki ukuran warna,harga,dan bentuk yang dimana dari semua ukuran itu dapat mempengaruhi keberadaan sebuah perusahaan tempat produk itu dibuat dan bahan-bahan apa saja yang digunakan dalam proses pembuatan produk tersebut,oleh karena itu seiring berjalannya waktu sebuah industri yang bergerak pada bidang pengolahan bahan harus bisa memperhatikan kualitas dari barang yang akan di hasilkan

Kualitas suatu produk juga dipengaruhi oleh beberapa faktor yang sering dikenal dengan 6M (Machine ,Material, Manpower, Method, Money, Motivation). Dari faktor diatas maka banyak penelitian-penelitian yang sudah dilakukan oleh para peneliti sebelumnya banyak mengemukakan penggunaan metode Six Sigma untuk menganalisis kualitas dari suatu produk yang dihasilkan.

Penelitian Sebelumnya oleh Rahul Panat, Valentina Dimitrova, Tamil Selvy Selvamuniandy, Kazuhiko Ishiko and Dennis Sun mengenai The application of Lean Six Sigma to the configuration control in Intel's manufacturing $R \& D$ environment, Penelitian ini menunjukkan bahwa setelah dilakukannya studi kasus dilingkungan R\&D ditemukan bahwa keunggulan dari oprasional pengembangan produk dapat diperoleh dengan penambahan teknologi baru. Selanjutnya penelitian dari Achmad Faizal Muttaqien tentang Analisis pengukuran kuantitas produk cacat pada mesin decorative tiles dengan menggunakan metode Six Sigma maka diperoleh Dari hasil analisis dan penelitian yang telah dilakukan ternyata jumlah produk kecacatan pada PT. Aster Decorindo Abadi berada di tingkat nilai sigma 3,23 dengan DPMO sebesar 40.348. Dari hal tersebut dapat diidentifikasikan bahwa ternyata kualitas produk masih berada jauh dari tingkat produk 6 Sigma. Dengan penggunaan alat analisis diagram sebab-akibat dapat diketahui faktor penyebab kerusakan produk dalam produksi yaitu berasal dari manusia, mesin,bahan baku dan lingkungan kerja.

Maka dari faktor dan penjelasan yang telah dipaparkan penulis memilih PT Bintan Bersatu Apparel yang juga merupakan salah satu perusahaan manufaktur yang bergerak dalam bidang pembuatan pakaian olahraga yang bersifat massal production sebagai bahan studi, perusahaan yang bersifat massal production memiliki arti perusahaan yang membuat produk dalam jumlah besar dan terus-menerus. Mengingat jumlah produksi yang banyak maka kecenderungan terjadinya pelanggaran kualitas akan sering terjadi di dalam proses produksi. Selain merupakan perusahaan yang bersifat massal production perusahaan ini harus benarbenar menjaga kualitas jahitan dan bahan yang digunakan agar konsumen dapat menggunakan produk dengan nyaman dan aman, mengingat produk akhir perusahaan ini adalah pakaian olahraga yang diperuntukkan utuk konsumen yang memiliki tingkat aktifitas yang tinggi. Sehingga perusahaan ini harus memiliki strategi untuk mempertahankan kualitas dari produk yang dihasilkannya dan mengurangi jumlah cacat produk yang akan terjadi berikutnya.

\section{KAJIAN PUSTAKA}

1. Kualitas

Kata kualitas memiliki pengertian sangat luas dan berbeda-beda sehingga arti kata kualitas memiliki konteks berbeda apabila sudah sampai ditangan konsumen. Oleh karna itu pengertian kualitas juga dikemukakan oleh para ahli yang dilihat dari sudut pandang produsen. Oleh karena itu definisi kualitas dapat diartikan dari dua perspektif, yaitu dari sisi konsumen dan sisi produsen.Namun pada dasarnya konsep dari kualitas sering dianggap sebagai kesesuaian, keseluruhan ciri-ciri atau karakteristik suatu produk yang diharapkan oleh konsumen.

Adapun pengertian kualitas menurut American Society For Quality yang dikutip oleh Heizer \& Render (2006): "Quality is the totality of features and characteristic of a product or service thatbears on it's ability to satisfy stated or implied need." Artinya kualitas/mutu adalah keseluruhan corak dan karakteristik dari produk atau jasa yang berkemampuan untuk memenuhi kebutuhan yang tampak jelas maupun yang tersembunyi.

Para ahli yang lainnya yang bisa disebut sebagai para pencetus kualitas juga mempunyai pendapat yang berbeda tentang pengertian kualitas, di antaranya adalah: Joseph Juran mempunyai suatu pendapat bahwa "quality is 
fitness for use" yang bila diterjemahkan secara bebas berarti kualitas (produk) berkaitan dengan enaknya barang tersebut digunakan (Suyadi Prawirosentono,2007).

Sifat khas mutu/kualitas suatu produk yang andal harus multidimensi karena harus memberi kepuasan dan nilai manfaat yang besar bagi konsumen, melalui berbagai cara. Oleh karena itu, sebaiknya setiap produk harus mempunyai ukuran yang mudah dihitung (misalnya, berat, isi, luas) agar mudah dicari konsumen sesuai dengan kebutuhannya.Di samping itu harus ada ukuran yang bersifat kualitatif, seperti warna yang unik dan bentuk yang menarik. Jadi terdapat spesifikasi barang untuk setiap produk, walaupun satu sama lain sangat bervariasi tingkat spesifikasinya.

Sebuah perusahaan juga harus bisa mempertahankan kualitas produk yang dihasilkannya.Oleh karena itu perusahaan harus bisa mengendalikan kualitas produknya agar tidak terjadi kegagalan produk atau cacat produk yang dapat meghasilkan dampak yang buruk bagi perusahaan itu sendiri.

Pengendalian merupakan kegiatan yang dilakukan untuk menjamin agar kegiatan produksi dan operasi yang dilaksanakan sesuai dengan apa yang telah direncanakan dan apabila terjadi penyimpangan tersebut dapat dikoreksi sehingga apa yang diharapkan tercapai.

\section{Faktor-Faktor Mendasar yang Menyebabkan Masalah Kualitas}

Ada 6 fakor yang dapat mempengaruhi kualitas suatu produk 6 faktor tersebut sering dikenal dengan 6M (Machine ,Material, Manpower, Method, Money, Motivation).

\section{1) Machine (Mesin)}

Kualitas produk yang baik berpengaruh terhadap mesin apa yang digunakan untuk memproduksi produk tersebut. Sebuah perusahan pada jaman sekarang sangat selektif dalam pemilihan mesin apa yang akan digunakan perusahaannya dalam memproduksi barang produksinya.

\section{2) Material (Bahan)}

Kualitas produk juga dipengaruhi oleh faktor bahan yang dipilih perusahaan dalam menghasilkan produknya.Tetapi pada saat ini perusahaan-perusahaan ingin sekali menekan biaya produksi sehingga perusahaan tersebut lebih ketat lagi dalam pemilihan bahan yang akan digunakan.

3) Manpower (Manusia)

Kualitas produk juga didasarkan oleh faktor manusia yang mengerjakan produk tersebut.Setiap perusahaan pasti ingin memiliki tenaga kerja yang berkompeten dan memiliki keahlian yang sesuai dengan pekerjaan yang akan dikerjakanya,Mengingat hal itu maka factor manusia juga merupakan salah satu factor yang sangat penting dalam menjaga kualitas sebuah produk.

\section{4) Method (Metode)}

Berkaitan dengan tidak adanya prosedur dan metode kerja yang benar, tidak jelas, tidak diketahui, tidak terstandarisasi, tidak cocok dan lainnya.

5) Money (Keuangan)

Berkaitan dengan ketiadaan dukungan financial (keuangan) yang mantap guna memperlancar proyek peningkatan kualitas Six sigma yang akan ditetapkan

\section{6) Motivation (Motivasi)}

Berkaitan dengan ketiadaan sikap kerja yang benar dan professional, yang dalam hal ini disebabkan oleh sistem balas jasa dan penghargaan yang tidak adil kepada tenaga kerja.

\section{METODE}

Penelitian dilaksana di PT Bitan Bersatu Apparel Batam yang beralamat Jl. Engku Putri No. 12 Batam Center. Kel.Belian, Kec.Batam Kota Batam, Kepulauan Riau, Indonesia. Penelitian dilaksanakan pada bulan Januari 2017- April 2017. Data dari penelitian ini didapat dari hasil wawancara, observasi langsung dan juga dokumentasi yang didapat selama penelitian. Analisis data pada penelitian ini menggunakan tahap DMAIC (Define, Measure, Analyse, Improve dan Control) yang digunakan untuk menyelesaikan masalah dan perbaikan kualitas terhadapproses produksi.

\section{Tahap Define}

Define merupakan tahap pertama dalam program peningkatan kualitas metode six sigma. Langkah operasional pertama yang akan dilakukan adalah menentukan sasaran dan tujuan peningkatan kualitas serta identifikasi cacat produk

\section{Tahap Measure}

Pada tahap ini dilakukan 2 tahap pengukurang yaitu tahap pengukuran 
Monica \& Shinta, analisis pengendalian kualitas produk garment pada project in line inspector ....

menggunakan P-Chart dan mengukur tingkat six sigma dan DPMO. Dalam melakukan pengendalian kualitas secara statistik, langkah pertama yang akan dilakukan adalah membuat check sheet. Check sheet berguna untuk mempermudah proses pengumpulan data serta analisis. Setelah check sheet dibuat dan setelah didapatkan hasil selanjutnya pengukuran menggunakan diagram $\mathrm{p}$-chart kemudian dari data yang tertera dapat di hitung nilai rata-rata produk akhir (CL) dengan rumus:

$$
C L=\frac{\sum n p}{\sum n}
$$

Sumber: Skripsi Achmad Muhaemin 2012

Kemudian setelah itu hitung nilai persentase kerusakan produk(p) dengan rumus :

$$
P=\frac{n p}{n}
$$

Sumber: Skripsi Achmad Muhaemin 2012

Selanjutnya cari nilai UCL dan LCL dengan rumus :

3.

$$
\begin{aligned}
& U C L=C L+3 \sqrt{\frac{C L(1-C L)}{n}} \\
& L C L=C L-3 \sqrt{\frac{C L(1-C L)}{n}}
\end{aligned}
$$

Diagram Pareto digunakan untuk mengetahui apakah ada produk yang rusak yang berada diluar batas control. Jika diketahui ternyata ada produk rusak yang berada diluar batas control maka diagram ini digunakan untuk menganalisa data yang di lihat berdasarkan urutan proporsi kerusakan terbesar hingga terkecil. Diagram pareto akan membntu memfokuskan pada masalah kerusakan produk yang lebih sering terjadi, dan juga dapat memberikan arahan untuk penanganan yang tepat rumus mencari \% kerusakan: 


\section{b. Diagram Sebab Akibat (Fishbone Diagram)}

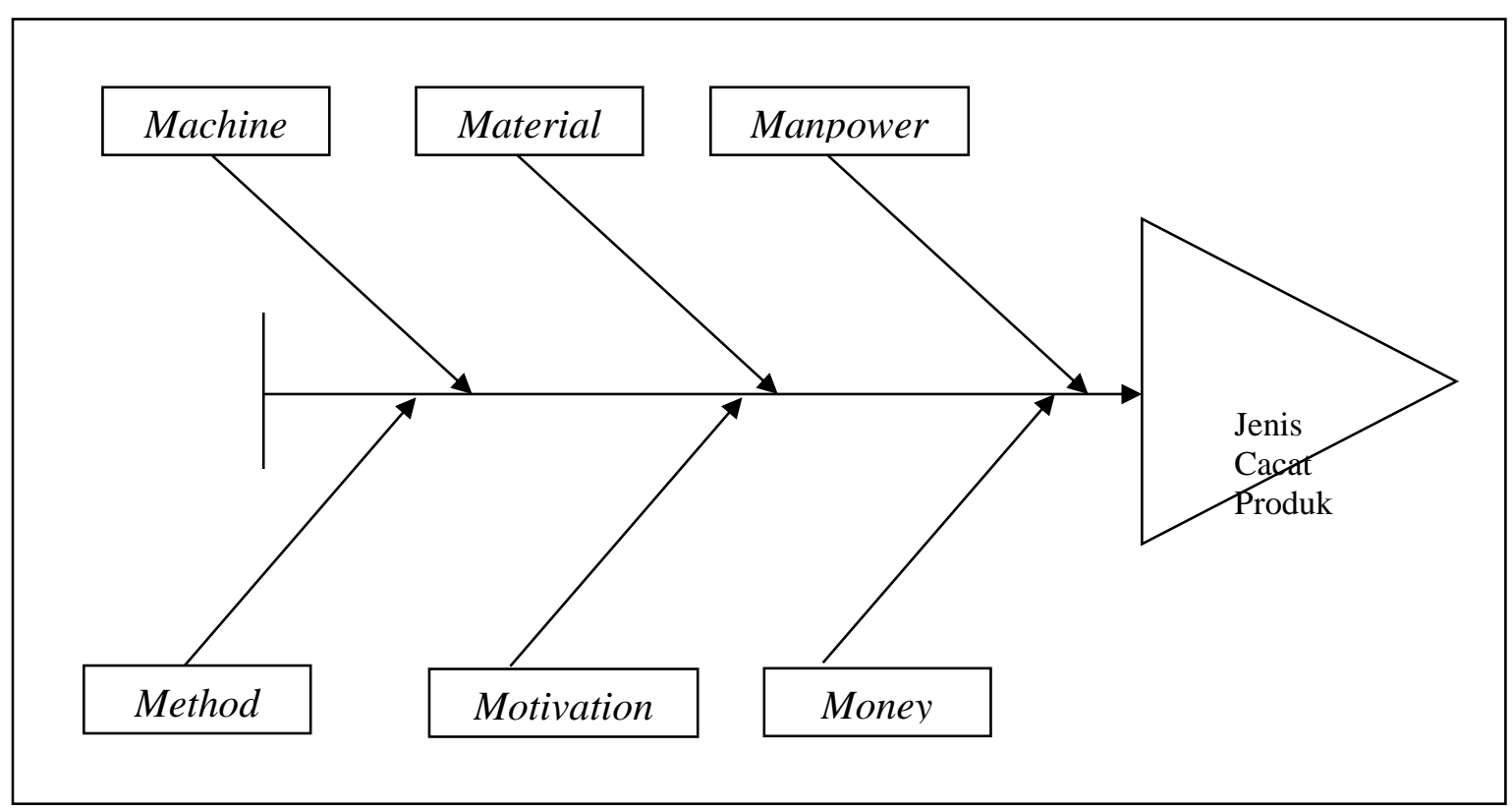

Gambar 1 Fishbone Diagram

\section{Tahap Improve}

Merupakan tahap peningkatan kualitas Six Sigma harus melakukan pengukuran(lihat dari peluang, kerusakan, proses kapabilitas saat ini), rekomendasi ulasan perbaikan, menganalisa kemudian tindakan perbaikan dilakukan. Improvement sendiri dapat dilakukan dengan cara FMEA (Failure Mode and Effect Analysis) yaitu metode analisa dengan mengidentifikasi penyimpangan potensial yang mungkin dan memberikan nilai kuantitatif terhadap setiap faktor yang diidentifikasi tersebut. Pemberian bobot atau nilai didapatkan melalui diskusi dengan manager quality, supervisor, line leader dan detectability pada setiap penyebab potensial yang diidentifikasi berdasarkan rating occurance, rating severity, dan rating detectability.

Rumus RPN $=\mathrm{O}$ x S x D

\section{Tahap Control}

Merupakan tahap peningkatan kualitas dengan memastikan level baru kinerja dalam kondisi standar dan terjaga nilai-nilai peningkatannya yang kemudian didokumentasikan dan disebarluaskan yang berguna sebagai langkah perbaikan untuk kinerja proses berikutnya.

\section{HASIL DAN PEMBAHASAN}

Berikut ini adalah hasil penelitian dan pengujian yang telah dilakukan :

\section{a. Tahap Define}

Define merupakan tahap pendefinisian masalah kualitas dalam produk pakaian olahraga di PT Bintan Bersatu Apparel, pada tahap ini yang menjadikan produk mengalami cacat didefinisikan jenis penyebabnya. Dengan berdasarkan pada sumber permasalahan yang diperoleh, 3 sumber produk cacat dapat didefinisikan berasal dari : Fabric (kain) cara kerja atau konstruksi pengerjaan, dan accessories. 
Monica \& Shinta, analisis pengendalian kualitas produk garment pada project in line inspector ....

1. Mendefinisikan masalah-masalah standar kualitas atau mendefinisikan penyebabpenyebab defect yang menjadi penyebab paling potensial dalam menghasilkan produk pakaian di PT Bintan Bersatu Apparel yang dilihat dari 3 sumber masalah penting. Tiga sumber masalah paling potensial dalam menghasilkan produk akhir diidentifikasikan sebagai berikut:

\section{a) Fabric (kain)}

Sumber ini adalah bahan baku yang dipakai untuk membuat suatu pakaian didalam fabric banyak penyebab yang dapat mempengaruhi kecacatan produk diantaranya: Cacat warna (beda warna di satu garment lainya, migrasi, luntur), cacat kain (bekas lipatan, berserabut, terkontaminasi), sisa kain pada jahitan, terpotong karena tergunting, salah ukuran size fabric.

\section{b) Cara kerja atau konstruksi pengerjaan}

Sumber ini didapat dari proses pengerjaan suatu produk proses ini dilihat pada bagian sewing produksi yang menjalankan proses produksi didalam sumber ini terdapat beberapa penyebab yang mengakibatkan kecacatan suatu produk diantaranya : Tidak sama panjang/gelombang diatas\&dijahitan penutup (cover stiching), jahitan terbuka/jahitan lari, jahitan berkerut/terjahit terjepit, terikat,melintir, gelombang, panjang pendek pada body /kaki bawah), bekas jarum terpotong dan bekas lubang jarum, kepadatan jahitan yang salah (contohnya lubang kancing, SPI, bordir), tidak ada tiktok atau bartek atau salah penempatanya, laminasi dan bergelembung dikarenakan salah lapisan, pemasangan hiasan yang tiak kuat atau berbahaya, salah kualitas 3 strip (3 garisan) posisi dan ukuran, detail kontruksi tidak semetris, Jahitan putus, ukuran diluar toleransi, berminyak, noda aneka jenis kotor bekas lem, masih ada sisa jahitan atau benang longgar, bekas pena atau kapur yang masih kelihatan, salah size warna bentuk posisi pada hiasan/ seni,cetakan yang tidak bagus, kualitas tempelan dengan panas (ada retak lengket berbau terkelupas dan tampilan yang tidak bagus), dan kesalahan pada jahitan border.

\section{c) Accessories}

Sumber ini berkaitan dengan dekorasi dan accessories yang terdapat dalam suatu produk seperti label zipper dan lain-lain. Didalam sumber ini ada beberapa penyebab kecacatan produk diantaranya: salah pemasangan aksesoris/ tidak ada/ tidak lengkap, hasil gosokan interlining kurang bagus, salah kemasan atau size, hilang informasi pada polybag atau karton/salah label.

2. Mendefinisikan rencana tindakan yang harus dilakukan berdasarkan hasil observasi dan analisis penelitian adalah:
a) Perbaikan pada mesin
b) Peningkatan kualitas tenaga kerja melalui training dan pelatihan khusus.
c) Pengawasan yang lebih ketat dengan metode yang tepat.
d) Prosedur kerja yang lebih jelas dan terarah.

3. Menetapkan sasaran dan tujuan peningkatan kualitas six sigma berdasarkan hasil observasi dan melalui pembuatan check sheet yang bertujuan : Mengurangi atau menekan prodak cacat dari 2,2\% menjadi $0 \%$. Terbukti dengan adanya total produk cacat tertinggi sebesar $2,2 \%$ dan terendah $1,8 \%$ berdasarkan persentase terendah sebenarnya PT Bintan Bersatu Apparel dapat menekan produk cacat hingga $0 \%$. Berdasarkan jenis sumber adanya produk cacat yang terdapat pada fabric, konstruksikerja dan proses kerja, hingga terdapat kekurangan pada accesories yang dapat menyebabkan kerugian bagi perusahaan maka perusahaan melakukan sesuatu perencanaan yang stategis dalam pengoperasionalnya dengan menekan produk cacat menjadi 0\% (zero defect) dengan tindakan yang tepat.

\section{b. Taham Measure}

Dari hasil check sheet kemudian dilakukan 2 tahap pengukuran jumlah produk cacat dan melakukan penghitungan batas kendali produk. 2 tahapan tersebut diantaranya: 
Journal of Applied Business Administration Volume 2, Nomor 1, Maret 2018, hlm. 29-45

1. Melakukan analisa pengukuran dengan menggunakan diagram p-chart dan didapat hasil dari perhitungan seperti table berikut:

Tabel 2 Penghitungan Batas Kendali dari Bulan Januari 2017 - April 2017

\begin{tabular}{|c|c|c|c|c|c|c|c|}
\hline NO & Periode & $\begin{array}{c}\text { Total Qty } \\
\text { yang di } \\
\text { cek (Pcs) } \\
\text { (n) }\end{array}$ & $\begin{array}{c}\text { Total } \\
\text { jumlah } \\
\text { produk } \\
\text { cacat } \\
\text { (Pcs) (Np) }\end{array}$ & $\begin{array}{c}\text { Persentase } \\
\text { Produk } \\
\text { cacat(\%) } \\
(\mathbf{P})\end{array}$ & LCL & CL & UCL \\
\hline 1 & Jan I & 50360 & 914 & 0.01815 & 0.01827 & 0.020 & 0.02202 \\
\hline 2 & Jan II & 55274 & 1077 & 0.01948 & 0.01835 & 0.020 & 0.02194 \\
\hline 3 & Jan III & 47995 & 1072 & 0.02234 & 0.01822 & 0.020 & 0.02207 \\
\hline 4 & Jan IV & 39621 & 794 & 0.02004 & 0.01803 & 0.020 & 0.02226 \\
\hline 5 & Jan V & 8141 & 178 & 0.02186 & 0.01547 & 0.020 & 0.02481 \\
\hline 6 & Feb I & 32762 & 696 & 0.02124 & 0.01782 & 0.020 & 0.02247 \\
\hline 7 & Feb II & 60895 & 1178 & 0.01934 & 0.01844 & 0.020 & 0.02185 \\
\hline 8 & Feb III & 46156 & 1029 & 0.02229 & 0.01818 & 0.020 & 0.02211 \\
\hline 9 & Feb IV & 53694 & 1037 & 0.01931 & 0.01832 & 0.020 & 0.02196 \\
\hline 10 & Feb V & 17003 & 349 & 0.02053 & 0.01691 & 0.020 & 0.02338 \\
\hline 11 & Mar I & 29685 & 616 & 0.02075 & 0.01770 & 0.020 & 0.02259 \\
\hline 12 & Mar II & 52906 & 1055 & 0.01994 & 0.01831 & 0.020 & 0.02198 \\
\hline 13 & Mar III & 52378 & 1009 & 0.01926 & 0.01830 & 0.020 & 0.02199 \\
\hline 14 & Mar IV & 58397 & 1202 & 0.02058 & 0.01840 & 0.020 & 0.02189 \\
\hline 15 & Mar V & 43015 & 889 & 0.02067 & 0.01811 & 0.020 & 0.02218 \\
\hline 16 & Apr I & 5441 & 109 & 0.02003 & 0.01443 & 0.020 & 0.02586 \\
\hline 17 & Apr II & 63680 & 1291 & 0.02027 & 0.01847 & 0.020 & 0.02181 \\
\hline 18 & Apr III & 51584 & 1030 & 0.01997 & 0.01829 & 0.020 & 0.02200 \\
\hline 19 & Apr IV & 56041 & 1085 & 0.01936 & 0.01836 & 0.020 & 0.02192 \\
\hline 20 & Apr V & 42985 & 875 & 0.02036 & 0.01811 & 0.020 & 0.02218 \\
\hline & Total & $\mathbf{8 6 8 0 1 3}$ & $\mathbf{1 7 4 8 5}$ & & & & \\
\hline
\end{tabular}

Sumber: Hasil Pengolahan Data Inline Excel 2010

Dari table kendali yang telah didapat maka didapat p-chart sebagai berikut: 
Monica \& Shinta, analisis pengendalian kualitas produk garment pada project in line inspector ....

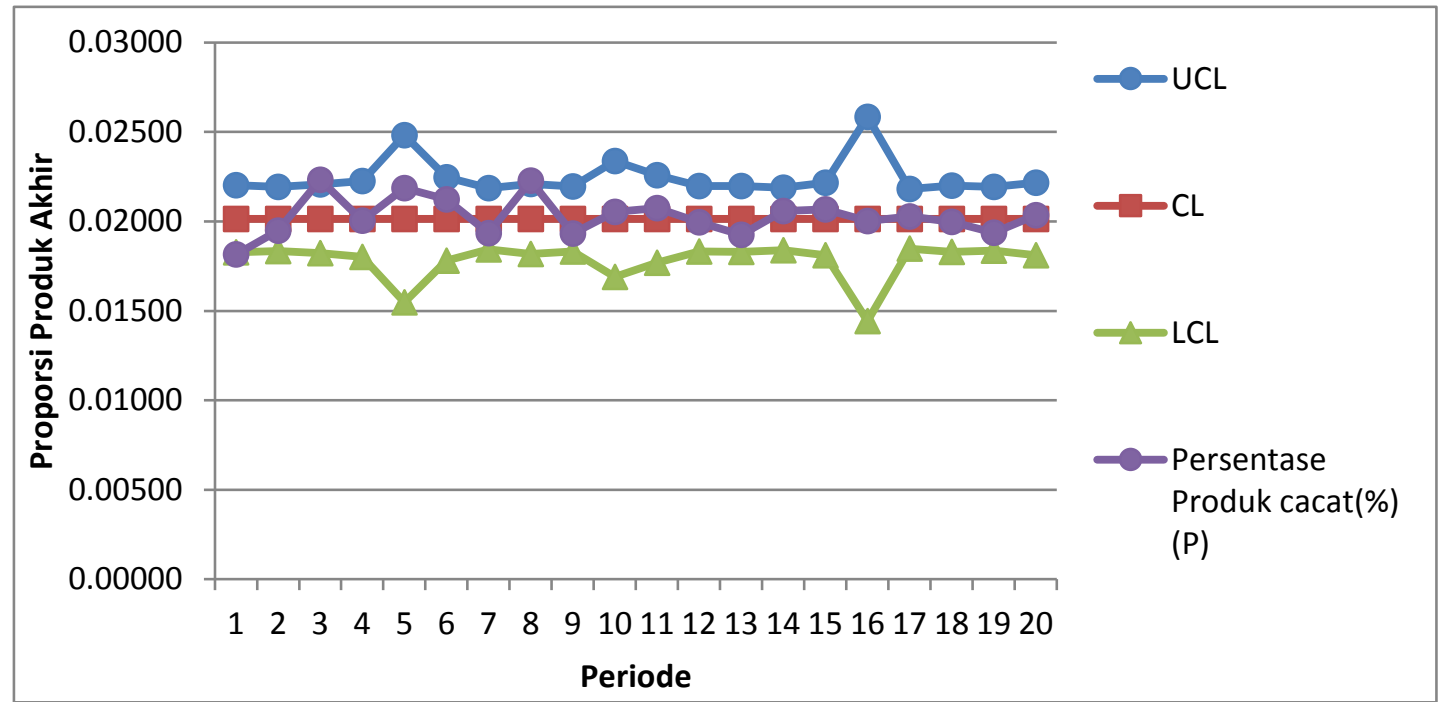

Grafik 1 Grafik Control P-Chart Periode Januari 2017- April 2017

Grafik Control P-Chart diatas menunjukkan terdapat dua titik periode terletak setara dengan batas UCL yang berarti hampir adanya out of control,yaitu:

a. Minggu ketiga bulan Januari 2017 atau minggu ke-3: proporsi produk akhir sebesar 0.02234 .

b. Minggu ketiga bulan Februari 2017 atau minggu ke-8: proporsi produk akhir sebesar 0.02229 .

Dari grafik diatas dapat disimpulkan karena $P$ lebih banyak berada diantara UCL

dan LCL maka kapabilitas proses berjalan dengan baik, sehingga hal itu

$$
D P U=\frac{\text { Total Kerusakan }}{\text { Total Produksi }}
$$

Sumber: Skripsi Achmad Muhaemin 2012 menjelaskan bahwa kapabilitas proses mampu memenuhi spesifikasi batas toleransi yang diinginkan namun perlu adanya pengendalian ketat dari perusahaan agar sampel yang lain tidak berada diluar batas kendali karena masih ada beberapa sampel yang berada di atas batas kendali UCL.

Setelah data $\mathrm{p}$-chart didapat selanjutnya dilakukan pengukuran tingkat sigma dan DPMO. Dan yang pertama sekalidilakuakn adalah mencari nilai DPU dengan rumus:

Lalu Setelah nilai DPU didapat maka kemudian dilanjut dengan mencari nilai DPMO dengan rumus :

DPMO $=\frac{\text { Total Kerusakan }}{\text { Total Produksi }} \times 1.000 .000$

Sumber: Skripsi Achmad Muhaemin 2012

Tabel 3 Pengukuran Tingkat Sigma dan Defect Per Million Opportunities (DPMO) Periode Januari 2017-April 2017

\begin{tabular}{|c|c|c|c|c|c|c|}
\hline NO & Periode & $\begin{array}{c}\text { Total Qty } \\
\text { yang di cek } \\
\text { (Pcs) (n) }\end{array}$ & $\begin{array}{c}\text { Total } \\
\text { jumlah } \\
\text { produk } \\
\text { cacat } \\
\text { (Pcs) (Np) }\end{array}$ & DPU & DPMO & $\begin{array}{c}\text { Nilai } \\
\text { Sigma }\end{array}$ \\
\hline 1 & Jan I & 50360 & 914 & 0.01815 & 18149 & 3.59 \\
\hline 2 & Jan II & 55274 & 1077 & 0.01948 & 19485 & 3.57 \\
\hline
\end{tabular}




\begin{tabular}{|c|c|c|c|c|c|c|}
\hline NO & Periode & $\begin{array}{c}\text { Total Qty } \\
\text { yang di cek } \\
\text { (Pcs) (n) }\end{array}$ & $\begin{array}{c}\text { Total } \\
\text { jumlah } \\
\text { produk } \\
\text { cacat } \\
\text { (Pcs) (Np) }\end{array}$ & DPU & DPMO & $\begin{array}{c}\text { Nilai } \\
\text { Sigma }\end{array}$ \\
\hline 3 & Jan III & 47995 & 1072 & 0.02234 & 22336 & 3.50 \\
\hline 4 & Jan IV & 39621 & 794 & 0.02004 & 20040 & 3.55 \\
\hline 5 & Jan V & 8141 & 178 & 0.02186 & 21865 & 3.52 \\
\hline 6 & Feb I & 32762 & 696 & 0.02124 & 21244 & 3.53 \\
\hline 7 & Feb II & 60895 & 1178 & 0.01934 & 19345 & 3.56 \\
\hline 8 & Feb III & 46156 & 1029 & 0.02229 & 22294 & 3.50 \\
\hline 9 & Feb IV & 53694 & 1037 & 0.01931 & 19313 & 3.56 \\
\hline 10 & Feb V & 17003 & 349 & 0.02053 & 20526 & 3.54 \\
\hline 11 & Mar I & 29685 & 616 & 0.02075 & 20751 & 3.54 \\
\hline 12 & Mar II & 52906 & 1055 & 0.01994 & 19941 & 3.56 \\
\hline 13 & Mar III & 52378 & 1009 & 0.01926 & 19264 & 3.57 \\
\hline 14 & Mar IV & 58397 & 1202 & 0.02058 & 20583 & 3.54 \\
\hline 15 & Mar V & 43015 & 889 & 0.02067 & 20667 & 3.54 \\
\hline 16 & Apr I & 5441 & 109 & 0.02003 & 20033 & 3.55 \\
\hline 17 & Apr II & 63680 & 1291 & 0.02027 & 20273 & 3.54 \\
\hline 18 & Apr III & 51584 & 1030 & 0.01997 & 19967 & 3.56 \\
\hline 19 & Apr IV & 56041 & 1085 & 0.01936 & 19361 & 3.56 \\
\hline 20 & Apr V & 42985 & 875 & 0.02036 & 20356 & 3.54 \\
\hline & Total & $\mathbf{8 6 8 0 1 3}$ & $\mathbf{1 7 4 8 5}$ & & & \\
\cline { 2 - 7 } & Rata- & & & $\mathbf{0 . 0 2 0 2 9}$ & $\mathbf{2 0 2 9 0}$ & $\mathbf{3 . 5 5}$ \\
\hline & rata & & & & & \\
\hline & & & & & & \\
\hline
\end{tabular}

Sumber: Hasil Pengolahan Data Inline Excel 2010

Dari tabel tersebut diketahui bahwa proses industri memiliki kapabilitas proses yang baik. Nilai DPMO dari bulan Januari sampai bulan April 2017 adalah 20.290 dan memiliki tingkat sigma sebesar 3.55 yang dapat jelaskan bahwa dari sejuta kesempatan yang ada akan terdapat 20.290 kemungkinan bahwa proses produksi itu

\section{c. Tahap Analysis}

\section{1) Diagram Pareto}

Data yang diolah untuk mengetahui persentase jenis produk yang di tolak. Dapat dihitung menggunakan rumus kerusakan sebagai berikut tidak mampu memenuhi toleransi yang ditetapkan perusahaan.

Hal ini menunjukkan pola DPMO dan pencapaian sigma yang belum konsisten, yang menunjukkan bahwa pola produksi belum dikelola dengan tepat

Sumber: Skripsi Achmad Muhaemin 2012

$$
\% \text { Kerusakan }=\frac{\text { Jumlah Jenis Kerusakan }}{\text { Jumlah Seluruh Kerusakan }} \times 100 \%
$$


Monica \& Shinta, analisis pengendalian kualitas produk garment pada project in line inspector ....

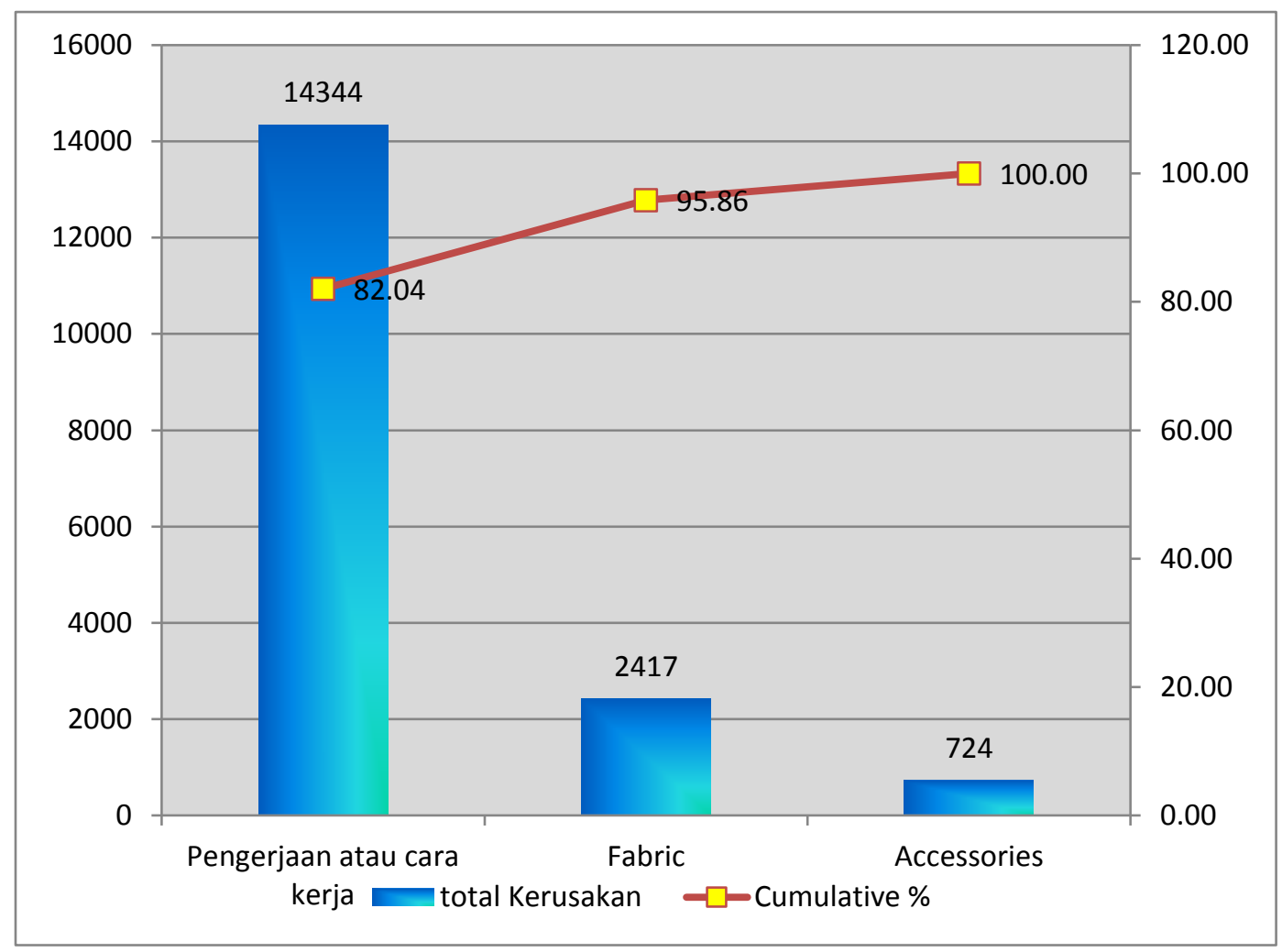

Gambar 2 Diagram Pareto Jenis Kecacatan Produk Pakaian Olahraga PT Bintan Bersatu Apparel dari Bulan Januari - April 2017

Dari diagram pareto gambar 3, penyebab kecatatan dilihat dari 3 jenis cacatnya yaitu cacat fabric cacat Pengerjaan atau konstruksi dan cacat accesories. Penyabab paling utama kecacatan yaitu pengerjaan atau konstruksi dengan persentase dari total kecacatan adalah 82.04\%. Sedangkan jenis kecacatan lainnya seperti Kecacatan fabric dan accessories masing-masing memiliki persentase $13.82 \%$ dan $4.14 \%$.

2) Diagram Sebab Akibat

\section{a. Cacat Fabric}

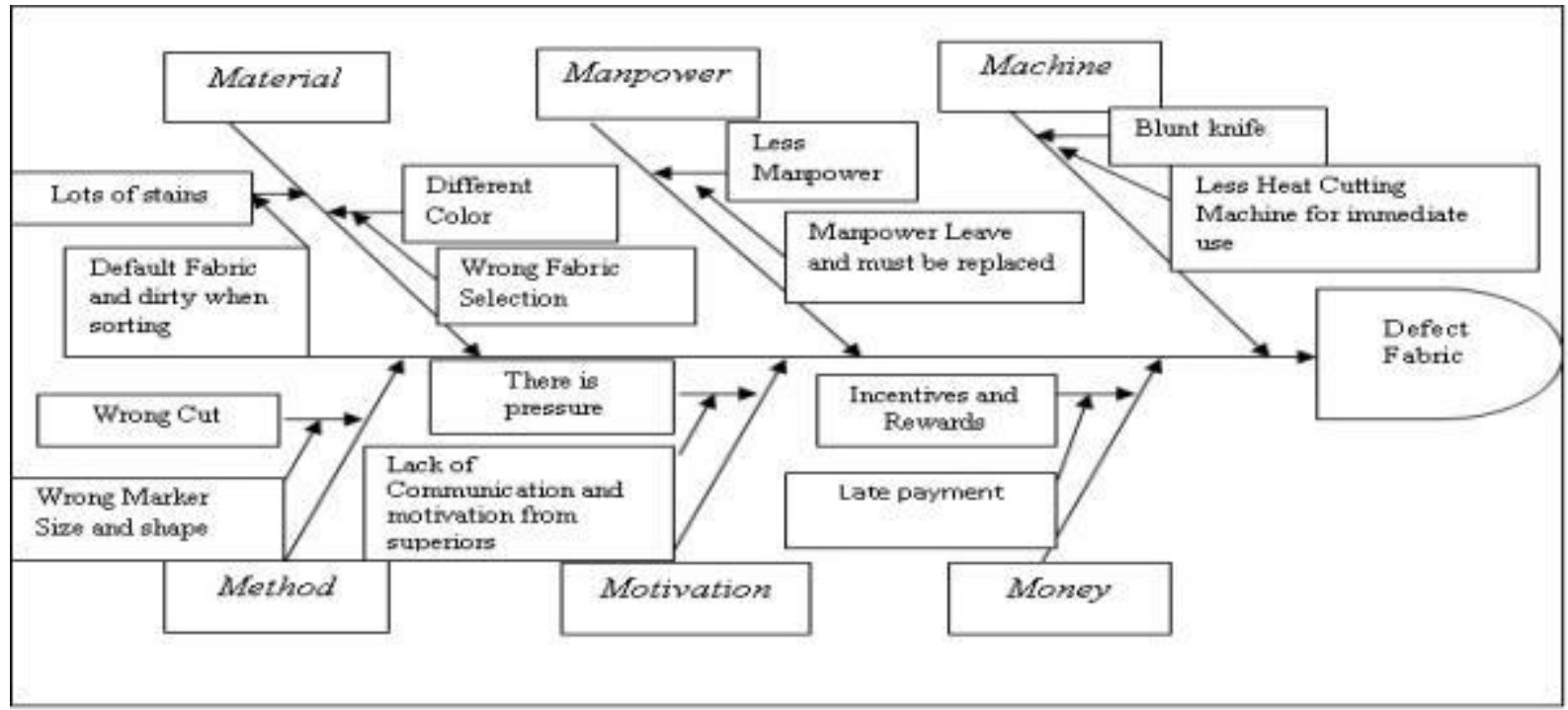

Gambar 3 Fishbone Diagram Cacat Fabric 
Jenis cacat pada fabric yang terdapat pada Gambar 3 diagram Sebab-Akibat cacat fabric dapat mengakibatkan terganggunya proses produksi yang akan berlangsung di bagian selanjutnya. Cacat Fabric pasti akan selalu ditemukan selama proses pengerjaan suatu produk, karena fabric yang akan dipotong disusun hingga pencapai 10-20 per bundle dan dipotong secara bersamaan yang hal ini dapat mengakibatkan kecacatan yangditemui pada fabric. Faktor-faktor penyebabnya sendiri dapat dilihat sebagai berikut:

a. Faktor Material

1. Banyak noda pada fabric diakibatkan bawaan fabric yang telah kotor dan bernoda pada saat pesanan fabric sampai kedalam perusahaan.

2. Beda warna dikarenakan karena saat proses sortir kain mengalami kesalahan pengambilan fabric di bagian store atau juga fabric yang di terima dari supplier juga telah berbeda dari pemesanan..

b. Faktor Manpower

Kurang manpower dikarenakan manpower mengambil cuti dan harus digantikan dengan karyawan lain yang tentunya harus dilatih lagi agar paham mnegoperasikan pekerjaan yang di gantikan.

c. Faktor Machine

Pisau tumpuldiakibatkan mesin pemotongan fabric kurang panas, hal ini dikarenakan mesin langsung dioperasikan saat pertama kali dibuka tanpa adanya pemanasan mesin terlebih dahulu.

d. Faktor Method

Fabric salah potong, hal ini diakibatkan marker atau pattern yang diterima mengalami salah ukuran dan bentuk.

\section{e. Faktor Motivation}

Terdapat tekanan yang dialami oleh karyawan yang diakibatkan kurangnya komunikasi antara atasan dan bawahan dan kurangnya motivasi yang di berikan atasan kepada karyawan.

f. Faktor Money

Karena insentive dan reward yang mengalami keterlambatan dalam penyerahaannya,dapat mengakibatkan karyawan menjadi malas dan mengabaikan tanggung jawabnya didalam perusahaan.

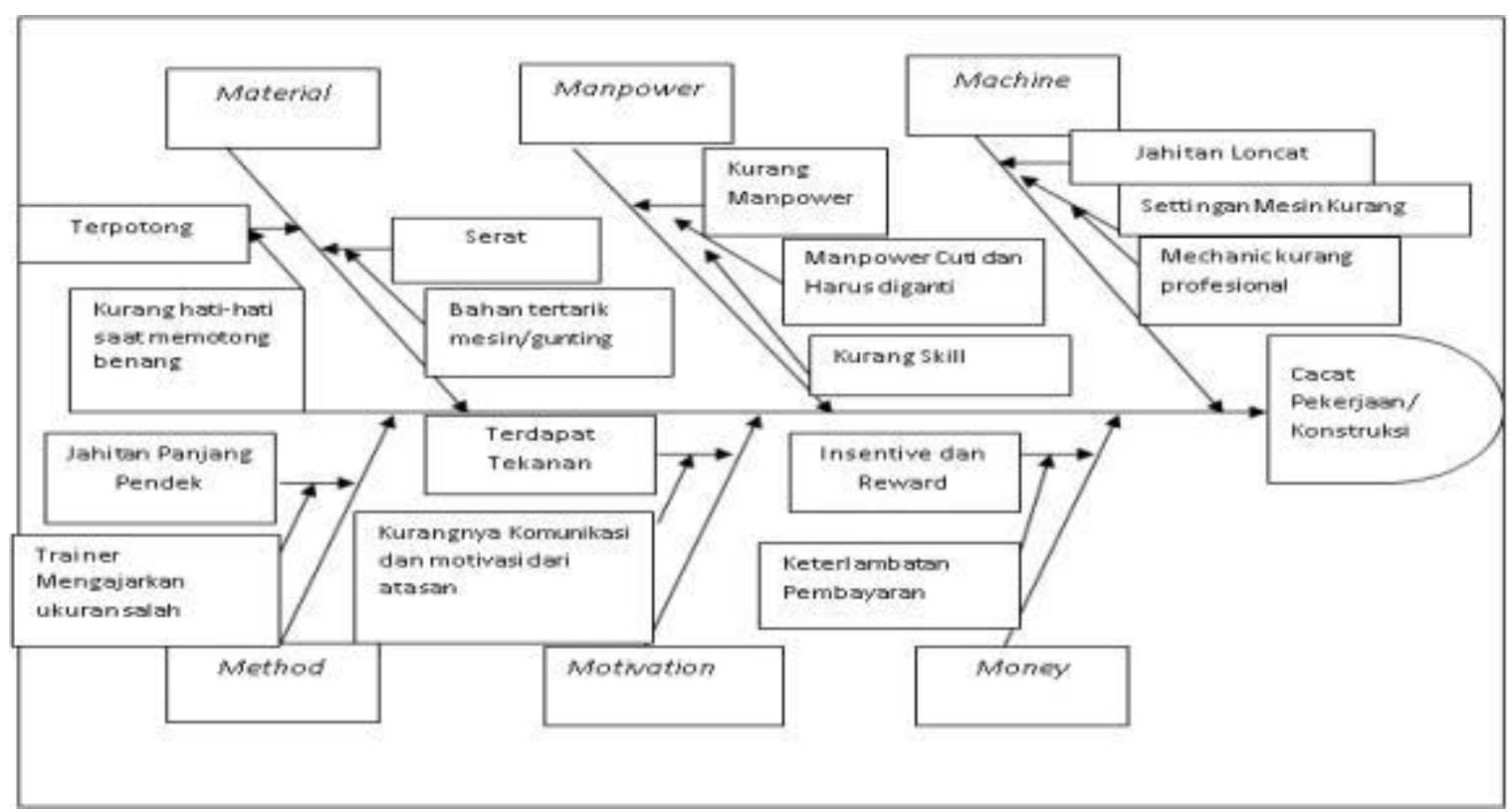

Gambar 4 Fishbone Diagram Cacat pengerjaan atau konstruksi

Jenis cacat pada pengerjaan atau konstruksi yang terdapat pada Gambar 4 Diagram Sebab-Akibat cacat pengerjaan atau konstruksi juga dapat mengakibatkan terganggunya proses produksi dan pengiriman barang kepada konsumen. Faktor-faktor tersebut diantaranya:

a. Faktor Material

Kain terpotong dikarenakan karyawan kurang hati-hati saat memotong bekas 
Monica \& Shinta, analisis pengendalian kualitas produk garment pada project in line inspector ....

sisa benang yang berdampak kain yang telah terjahit ikut terpotong.

1. Kain Serat diakibatkan saat proses menjahit,bahan tertarik oleh mesin atau tertarik gunting saat memotong sisa kain

b. Faktor Manpower

Kurang manpower dikarenakan manpower mengambil cuti dan harus digantikan dengan karyawan lain yang tentunya harus dilatih lagi agar paham mnegoperasikan pekerjaan yang di gantikan.

\section{c. Faktor Machine}

Jahitan loncat dakibatkan settingan mesin kurang benar yang dikarenakan pada saat mekanik menyeting mesin kurang memperhatikan settingan yang diminta atau juga karena benang yang tersangkut ke mesinkarena terkena angin. d. Faktor Metode

Jahitan panjang pendek yang diakibatkan pada saat changeover trainer mengajarkan karyawan cara pengukuran yang salah.

\section{e. Faktor Motivation}

Terdapat tekanan yang dialami oleh karyawan yang diakibatkan kurangnya komunikasi antara atasan dan bawahan dan kurangnya motivasi yang di berikan atasan kepada karyawan.

f. Faktor Money

Karena insentive dan reward yang mengalami keterlambatan dalam penyerahaannya, dapat mengakibatkan karyawan menjadi malas dan mengabaikan tanggung jawabnya didalam perusahaan.

\section{e. Cacat Accessories}

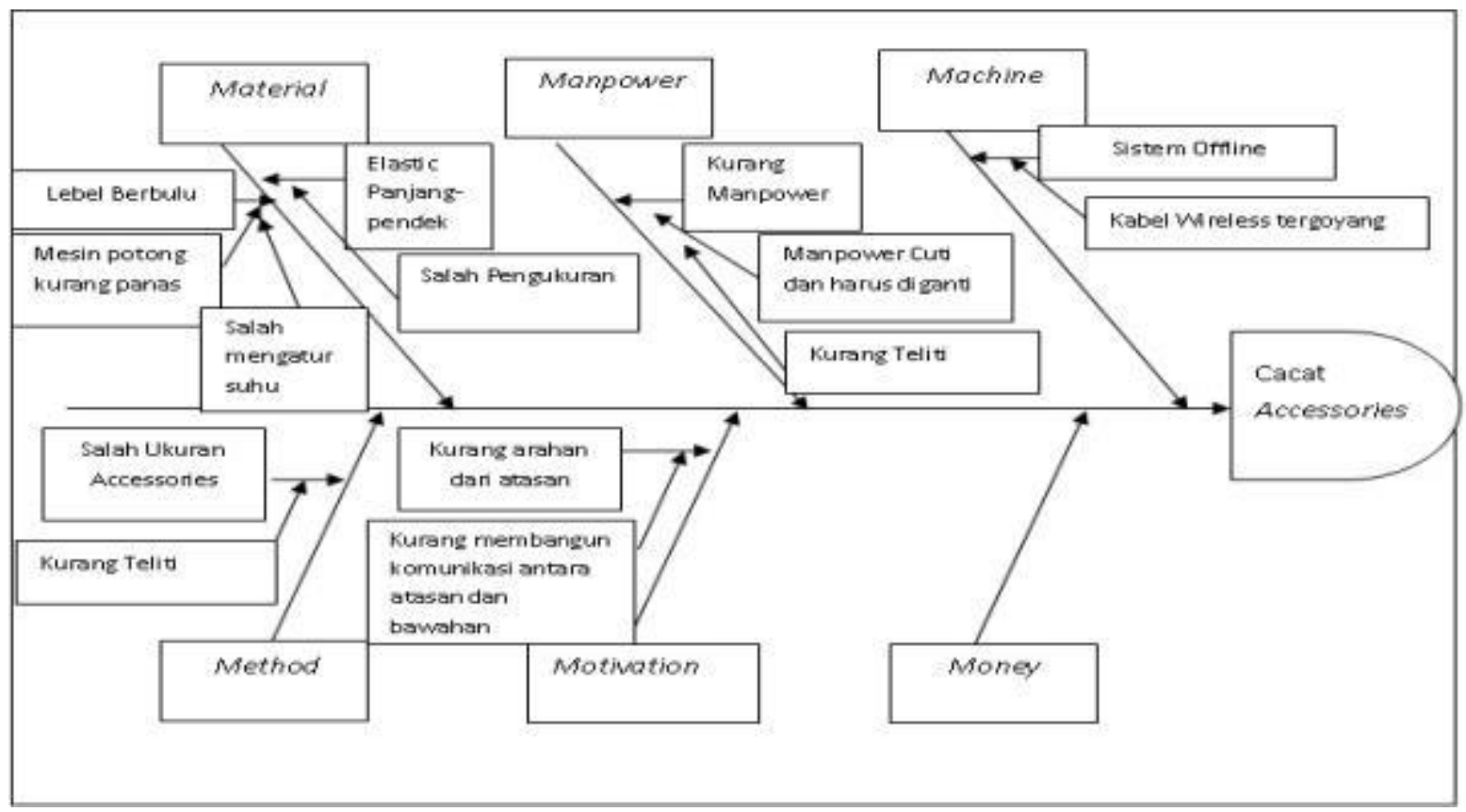

\section{Gambar 5 Fishbone Diagram Cacat Accessories}

Jenis cacat ini juga dapat mengakibatkan keterlambatan pengiriman karna accessories merupakan part penting didalam sebuah pakaian yang terdiri dari label, karet, $\log$ o dan sebagainya.berikut beberapa faktor yang menyebabkan kecacatan pada accessories:

\section{a. Faktor Mesin}

Pada faktor ini dilihat penyebab terjadinya kerusakan pada accessories seperti mesin yang mengalami sistem offline yang mengakibatkan accessories yang akan digunakan terhambat proses distribusi kebagian sewing.

b. Faktor Material

1. Label berbulu yang diakibatkan mesin potong label kurang dilakukan pemanasan dan langsung di operasikan, dan dapat juga 
diakibatkan kesalahan pengaturan suhu saat pengoperasian mesin.

2. Elastic panjang pendek dikarenakan saat elastic dipotong terjadi kesalahan pengukuran.

c. Faktor Manpower

Kurang manpower dikarenakan manpower mengambil cuti dan harus digantikan dengan karyawan lain yang tentunya harus dilatih lagi agar paham mnegoperasikan pekerjaan yang di gantikan.

\section{d. Faktor Method}

Salah ukuran accessories dikarenakan karyawan kurang teliti saat melakukan pengukuran.

\section{e. Faktor Motivation}

Terdapat tekanan yang dialami oleh karyawan yang diakibatkan kurangnya komunikasi antara atasan dan bawahan dan kurangnya motivasi yang di berikan atasan kepada karyawan.

\section{d. Tahap Improve}

Pada tahap ini digunakan metode FMEA untuk meningkatkan proses berdasarkan pada tahap analyze. Dari tabel FMEA diperoleh RPN, dimana perhitungan nilai RPN ini dilakukan setelah penentuan severity, occurance dan detection yang telah diidentifikasi dari hasil brainstorming dengan pihak yang berkompeten di perusahaan dalam hal ini data didapat dari bagian quality department. Adapun hasil improvement menggunakan metode FMEA dapat dilihat pada table berikutBerdasarkan pada tabel FMEA tersebut, didapat nilai RPN tertinggi untuk cacat pengerjaan atau konstruksi jahitan sebesar 126 RPN dan cacat fabric khusus cacat warna sebesar 60 RPN. Dari tabel dapat dilihat faktor manusia dan mesin merupakan faktor yang sangat berpengaruh dalam penghasilan produk dilihat dari hasil analisis, sehingga proses improvement adalah yang tepat telah dijabarkan dan telah direkomendasikan pada Tabel RPN diatas.

Tabel 4 FMEA dan Total RPN dan Proses Improvement

\begin{tabular}{|c|c|c|c|c|c|c|c|c|c|c|}
\hline \multirow{2}{*}{$\stackrel{0}{Z}$} & \multirow{2}{*}{ 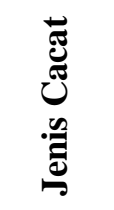 } & \multirow{2}{*}{ 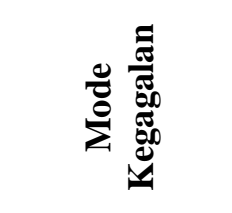 } & \multicolumn{2}{|c|}{ Potensi Efek Kegagalan } & \multirow{2}{*}{ 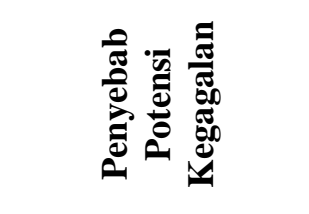 } & \multirow{2}{*}{ 悹 } & & \multirow{2}{*}{ 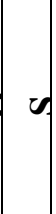 } & \multirow{2}{*}{$\theta$} & \multirow{2}{*}{ Z } \\
\hline & & & $\begin{array}{c}\text { Proses } \\
\text { Berikutnya }\end{array}$ & $\begin{array}{l}\text { Performansi } \\
\text { Produk }\end{array}$ & & & & & & \\
\hline 1 & $\begin{array}{l}\text { Cacat } \\
\text { Fabric }\end{array}$ & $\begin{array}{l}\text { Cacat warna } \\
\text { (beda warna } \\
\text { di satu } \\
\text { garment atau } \\
\text { lainya } \\
\text { migrasi, dan } \\
\text { luntur) }\end{array}$ & $\begin{array}{l}\text { tidak dapat } \\
\text { di tampel } \\
\text { label dan } \\
\text { logo }\end{array}$ & $\begin{array}{l}\text { kain yang cacat } \\
\text { warna tidak } \\
\text { dapat diproduksi } \\
\text { dan harus } \\
\text { dilakukan } \\
\text { pengecekan dan } \\
\text { penggantian } \\
\text { fabric baru } \\
\text { (Potong ulang) }\end{array}$ & $\begin{array}{l}\text { Human Error: } \\
\text { Kesalahan } \\
\text { pemilihan Fabric } \\
\text { dan salah } \\
\text { informasi Method: } \\
\text { Salah meletakkan } \\
\text { fabric Material: } \\
\text { Bawaan material } \\
\text { Fabric yang } \\
\text { memang sudah } \\
\text { reject }\end{array}$ & $\begin{array}{l}\text { Pengawasan } \\
\text { terhadap pekerja } \\
\text { dan memperbaiki } \\
\text { sistem } \\
\text { komunikasi yang } \\
\text { berlangsung di } \\
\text { daerah Fabric }\end{array}$ & 3 & 4 & 5 & 60 \\
\hline 2 & $\begin{array}{c}\text { Cacat } \\
\text { Penger } \\
\text { jaan \& } \\
\text { Konstr } \\
\text { uksi }\end{array}$ & $\begin{array}{l}\text { Konstruksi } \\
\text { Jahitan } \\
\text { (terbuka/jahit } \\
\text { an } \\
\text { lari,berkerut/ } \\
\text { terjahit } \\
\text { terjepit, } \\
\text { terikat,melinti } \\
\text {, gelombang, } \\
\text { panjang }\end{array}$ & $\begin{array}{l}\text { Operation } \\
\text { Step } \\
\text { berikutnya } \\
\text { tertunda } \\
\text { pengerjaan- } \\
\text { nya }\end{array}$ & $\begin{array}{l}\text { Jahitan yang } \\
\text { bermasalah dari } \\
\text { setiap operation } \\
\text { tidak dapat } \\
\text { dilanjut } \\
\text { pengerjaannya, } \\
\text { karena dapat } \\
\text { menghambat } \\
\text { pengerjaan pada }\end{array}$ & $\begin{array}{l}\text { Human error: } \\
\text { tidak } \\
\text { memperhatikan } \\
\text { marking yang telah } \\
\text { di sediakan } \\
\text { sehingga } \\
\text { berpengaruh pada } \\
\text { hasil jahitan, tidak } \\
\text { melakukan self } \\
\text { check terhadap }\end{array}$ & $\begin{array}{l}\text { Pengawasan } \\
\text { terhadap operator } \\
\text { untuk setiap } \\
\text { operation } \\
\& \text { mengingatkan } \\
\text { untuk Self Check } \\
\text { hasil kerjaan } \\
\text { sebelum sampai } \\
\text { ke QC, untuk } \\
\text { mesin dilakukan }\end{array}$ & 7 & 3 & 6 & 126 \\
\hline
\end{tabular}


Monica \& Shinta, analisis pengendalian kualitas produk garment pada project in line inspector ....

\begin{tabular}{|c|c|c|c|c|c|c|c|c|c|}
\hline \multirow{2}{*}{ Z } & \multirow{2}{*}{ 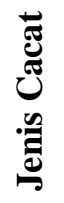 } & \multirow{2}{*}{ 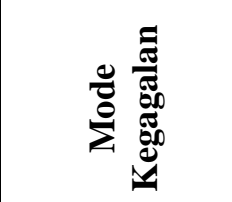 } & \multicolumn{2}{|c|}{ Potensi Efek Kegagalan } & \multirow{2}{*}{ 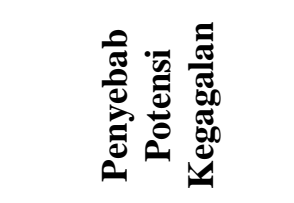 } & \multirow{2}{*}{ 醇 } & & \multirow{2}{*}{$=$} & \multirow{2}{*}{$\underline{z}$} \\
\hline & & & $\begin{array}{c}\text { Proses } \\
\text { Berikutnya }\end{array}$ & $\begin{array}{l}\text { Performansi } \\
\text { Produk }\end{array}$ & & & & & \\
\hline & & $\begin{array}{l}\text { pendek pada } \\
\text { body /kaki } \\
\text { bawah, } \\
\text { jahitan putus, } \\
\text { Tidak sama } \\
\text { panjang/ } \\
\text { gelombang } \\
\text { diatas\&dijahit } \\
\text { an penutup } \\
\text { (cover } \\
\text { stiching), } \\
\text { masih ada } \\
\text { sisa jahitan } \\
\text { atau benang } \\
\text { longgar }\end{array}$ & & $\begin{array}{l}\text { operation } \\
\text { selanjutnya }\end{array}$ & $\begin{array}{l}\text { produk yang } \\
\text { dikerjakan, Mesin } \\
\text { : Settingan mesin } \\
\text { yang tidak pas } \\
\text { Material : bahan } \\
\text { yang digunakan } \\
\text { terlalu } \\
\text { tipis/tebal/licin, } \\
\text { tanda pada kain } \\
\text { tidak sesuai antara } \\
\text { satu dengan yang } \\
\text { lainnya, Metode : } \\
\text { terdapat masalah } \\
\text { handling pada } \\
\text { setiap manpower }\end{array}$ & $\begin{array}{l}\text { perbaikan } \\
\text { \&penyetelan } \\
\text { ulang mesin \& } \\
\text { jika mesin tidak } \\
\text { juga bagus akan } \\
\text { dilakukan } \\
\text { penggantian } \\
\text { mesin, untuk } \\
\text { bahan yang } \\
\text { digunakan } \\
\text { dilakukan } \\
\text { penanganan } \\
\text { personal dari } \\
\text { Supervisor dan } \\
\text { Leader untuk } \\
\text { menjaga qualitas } \\
\text { bahan sensitif di } \\
\text { setiap line, untuk } \\
\text { metode yang } \\
\text { digunakan } \\
\text { dilakukan } \\
\text { pengecekan } \\
\text { handling } \\
\text { manpower } \\
\text { dengan } \\
\text { menerapkan } \\
\text { sistem GSD }\end{array}$ & & & \\
\hline
\end{tabular}

\section{e. Tahap Control}

Control merupakan tahap analisis terakhir dari six sigma yang menekankan pada pendokumentasian dan penyebarluasan dari tindakan yang telah dilakukan meliputi:

a. Melakukan perawatan dan perbaikan mesin secara berkala, dan melakukan pergantian mesin yang sudah tua.

b. Melakukan pengawasan terhadap bahan baku yang masuk kedalam area produksi dan melakukan pengawasan karyawan bagian produksi agar mutu barang yang dihasilkan lebih baik, serta dilakukan training khusus kepada karyawan untuk menjaga kualitas produk yang dikerjakan.

c. Melakukan pencatatan dan penimbangan seluruh produk catat setiap hari dari masing-masing jenis dan mesin, yang dilakukan oleh karyawan dalam proses produksi.

d. Melaporkan hasil penimbangan produk cacat berdasarkan type produk catat kepada supervisor.

Total produk cacat dalam periode satu bulan dicantumkan dalam montly Inline Record, dan data yang telah ada kemudian atas pertanggung jawaban manajer produksi akan dilaporkan kepada direktur perusahaan oleh department terkait.

\section{SIMPULAN DAN SARAN}

1. Berdasarkan data produksi yang diperoleh PT Bintan Bersatu Apparel diketahui jumlah produksi pada bulan Januari 2017 sampai dengan April 2017 adalah sebesar 868.013 Pcs dengan jumlah produk cacat yang terjadi dalam produksi sebesar 17.485 Pcs. Berdasarkan perhitungan, PT Bintan 
Bersatu Apparel memiliki tingkat sigma 3.55 dengan kemungkinan kerusakan sebasar 20.290 untuk sejuta produksi (DPMO). Hal ini tentunya menjadi sebuah kerugian yang sangat besar apabila tidak ditangani sebab semakin banyak produk yang gagal dalam proses produksi tentunya mengakibatkan pembengkakan biaya produksi.

2. Jenis-jenis kerusakan yang sering terjadi pada produksi PT Bintan Bersatu Apparel berasal dari kecacatan fabric sebanyak 2.417 pcs dengan persentase kerusakan $13.82 \%$, cacat pengerjaan atau konstruksi sebanyak 14.344 pcs dengan persentase kerusakan $82.04 \%$, serta jenis kecacatan accessories berjumlah 724 pcs dengan persentase $4.14 \%$.

3. Berdasarkan hasil pengukuran yang telah dilakukan maka di dapartkan hasil jumlah persentase kecacatan yang diperoleh paling banyak adalah kecacatan yang diakibatkan oleh proses pengerjaan atau konstruksi yang mencapai $82.04 \%$.

\section{Saran}

Dari hasil pembahasan dan kesimpulan penelitian, dapat dikemukakan beberapa saran yang dapat dipertimbangkan oleh perusahaan sebagai berikut:

1. Machine: Mesin yang sudah tua dan usang serta umur ekonomis mesin yang sudah habis sebaiknya diganti dengan mesin yang lebih baru dan canggih. Perusahaan memerlukan cukup waktu untuk mengumpulkan dana yang tidak sedikit. Oleh karena itu sebagai antisipasi agar mesin tetap bekerja dengan maksimal, perawatan dan perbaikan mesin harus dilakukan lebih intensif dan terus-menerus paling tidak dalam sebulan dilakukan pengecekan berkala untuk mesin-mesin yang paling sering digunakan .

2. Manpower: Leader dan Supervisor bertanggung jawab terhadap produk cacat diareanya masing masing serta bertanggung jawab memupuk tingkat kesadaran karyawan terhadap pekerjaan yang sdang dikerjakan, dapat pula dengan cara peningkatan keterampilan dan kesadaran karyawan serta mensosialisaskan metode kerja yang digunakan pada karyawan dengan memberikan pelatihan kerja (job training) dapat membantu meningkatkan hasil produktifitas dan mengurangi produk cacat yang dihasilkan.

3. Method: Membuat suatu perencanaan kerja yang tersusun sehingga mudah dalam penyampaian informasi, pengamatan hasil perbaikan selama satu minggu, pengelompokkan produk cacat berdasarkan jenis dan mesin dan melakukan evaluasi metode yang digunakan pekerja selama menghasilkan produk menggunakan system GSD.

4. Material: Selektif tehadap pemasok dan memperketat penyeleksian bahan baku yang akan digunakan dalam proses produksi serta melakuakan pengawasan terhadap bahan baku, yaitu dengan cara pemilihan bahan baku yang sesuai dengan standar yang diinginkan perusahaan.

5. Motivasi : setiap karyawan seluruh department perlu diberi motivasi untuk meningkatkan kinerja dalam upaya menciptakan Total Quality Management (TQM) yang baik. Kesadaran pentingnya peningkatan kualitas diberikan melalui pelatian motivasi dan seminar, dorongan dari pimpinan, serta motivasi berupa pemberian penghargaan bagi karyawan yang berprestasi.

6. Money : Untuk masalah keuangan perusahaaan dapat mengatur lebih terperinci lagi penggunaan aliran dana untuk proses produksi serta dapat memberikan tunjangan berupa gaji, reward, dan upah lembur tepat waktu kepada pekerja agar pekerja dapat terus bersemangat menghasilkan produk yang berkualitas.

\section{DAFTAR PUSTAKA}

Cendrawati, Nenny Ika (2007). Rancangan Pengendalian Mutu dengan Metode Six Sigma pada Divisi Spinning PT Unitex Tbk Bogor. Departmen Manajemen Fakultas Ekonomi dan Manajemen,Institut Pertanian Bogor.

Desai,Tushar.N.,Shrivastava,R.L(2008).Six

Sigma-A New Direction to Quality and Productivity Management. Proceeding of the World Congress on Engineering and Computer Science 2008 
Monica \& Shinta, analisis pengendalian kualitas produk garment pada project in line inspector ....

Fransiscus, Hanky., Juwono, Cyntia Prithadevi., Astari, Isabelle Sarah (2014). Implentasi Metode Six Sigma DMAIC untuk Mengurangi Paint Bucket Cacat di PT X.Jurnal Rekayasa Sistem Industri Vol 3,No.2,2014. hlm 54-64

Gaspersz,Vincent(2008).The Executive Guide to Implementing Lean Six Sigma. Jakarta: Gramedia Pustaka Utama.

Ganguly, Kunal (2012). Improvement Process for Rolling Mill Through the DMAIC Six Sigma Approach. International Journal for Quality Research Vol 6,No.13,2012.hlm 221-231

Hanif, Richma Yulinda, Hendang Setyo Rukmi, Susy Susanty (2015). Perbaikan Kualitas Produk Keraton Luxury di PT.X dengan Menggunakan Metode Failure Mode and Effect Analysis (FMEA) dan Fault Tree Analysis (FTA).Jurnal Teknik Industri Itenas No.3 Vol.03 Juli 2015.hlm 137-147

Kabir, Md., Enamul, Boby S.M. Mahbubul Islam., Lutfi, Mustafa (2013). Productivity Improvement by Using Six Sigma. International Jurnal of Engineering and Technology Vol 3 No.12,December,2013.hlm 1057-1084

Lusiana,Anna(2007).Analisis Pengendalian Kualitas Produk dengan Menggunakan Metode Six Sigma Pada PT Sandang Nusantara Unit Patal Secang .Jurusan Akuntansi Fakultas Ekonomi, Universitas Negeri Semarang.

Munaemin, Achmad (2012). Analisis Pengendalian Kualitas Produk dengan Metode Six Sigma Pada Harian Tribun Timur. Jurusan Manajemen Fakultas Ekonomi Bisnis, Universitas Hassanudin. $103 \mathrm{Hal}$

Narula, Virender., Gover, sandeep (2015). Six Sigma: Literature Review Implications For Future Research. International Journal of Industrial Engineering and Production Research. Hlm 13-26

Oktavianto,Diky(2013).Analisis Kecacatan Produk Aqua Dalam Upaya Perbaikan Kualitas Dengan Metode DMAIC (Study Kasus:PT AQUA Golden Mississipi). Program Studi Matematika, Universitas Pakuan Bogor.

Pepper,M.P.J., Spedding, T.A (2010).The Evolution of Lean Six Sigma.
International Journal of Quality and Reliability Management Vol 27,No.2 2010. hlm 138-155.

Parlaungan (2011).Quality Control Untuk Produk Kertas PT X Paper Products Menggunakan Metode Six Sigma. Program Studi Matematika Fakultas Sains dan Teknologi, Universitas Islam Negeri Syarif Hidayatullah.

Pyzdek,Thomas(2013).The Six Sigma Handbook Revised and Expended. NewYork: McGraw-Hill Companies. inc.

Suryana(2010). Metodologi Penelitian Model Prakatis Penelitian Kuantitatif dan Kualitatif. Bandung:Universitas Pendididkan Indonesia

Sugiyono(2009).Metode Penelitian Bisnis (Pendekatan Kuantitatif, Kualitatif dan $R \& D)$. Bandung: CV. Alfabet. 